\title{
Initial development of coffee seedlings in the presence of plant extracts
}

\author{
Bruna Penha Costa ${ }^{1}$, José Barbosa Duarte Júnior ${ }^{1}$, Luanna Karoline Rinaldi² ${ }^{2}$ Carlos \\ Augusto Rocha de Moraes Rego ${ }^{1}$, José Renato Stangarlin ${ }^{1}$
}

\author{
${ }^{1}$ Universidade Estadual do Oeste do Paraná, Campus Marechal Cândido Rondon, Marechal Cândido Rondon, Paraná, Brasil. E-mail: \\ bruna.penhacosta@hotmail.com, bduarte7@yahoo.com.br, cassielcarlos@hotmail.com, jose.stangarlin@unioeste.br
}

${ }^{2}$ Universidade Estadual de Maringá, Campus de Maringá, Maringá, Paraná, Brasil. E-mail: lu.rinaldi@ hotmail.com

Received: 13/03/2020; Accepted: 22/07/2020.

\begin{abstract}
The coffee plant can grow together with different plants, but the presence of allelochemicals can affect the crop post-planting. This study aimed to evaluate the early growth of coffee seedlings following treatment with plant extracts from different botanical families. The experimental design used randomized blocks with four trials, in a 7 $\times 2$ factorial scheme; the first factor consisted of aqueous extracts from six species: canola, crotalaria, brachiaria, sunflower, wheat, and lupine; water was used as the control. The second factor comprised of different botanical parts of the aforementioned six species of plant. The extracts were diluted to $5 \%$ concentration and were applied at a dose of $20 \mathrm{~mL}$ per plant. The agronomic variables analyzed were plant height (PH), stem diameter (SD), leaf area index (LAI), leaf dry matter (LDM), root dry matter (RDM), and root length (RL). Compared to the canola extract, the application of brachiaria extract resulted in the best response in $\mathrm{PH}$, regardless of the botanical part that constituted the extract, leading to an increase in $\mathrm{PH}$ by $3.77 \mathrm{~cm}$. The agronomic character most sensitive to the application of aqueous extracts was $\mathrm{PH}$, in which the brachiaria extract was prominent in inducing the greatest growth, whereas the canola extract hindered the initial development of Arabica coffee seedlings.
\end{abstract}

Keywords: allelopathy, Coffea arabica L., plant consortium.

\section{Desenvolvimento inicial de mudas de café na presença de extratos vegetais}

\section{RESUMO}

O cafeeiro pode conviver com diferentes plantas; dessa relação, é esperada a presença de aleloquímicos que podem afetar a cultura desde o pós-plantio. Este trabalho teve o objetivo de avaliar o desenvolvimento inicial de mudas de café utilizando extratos vegetais de diferentes famílias botânicas. O delineamento experimental foi em blocos casualizados com quatro repetições, em esquema fatorial 7 x 2, cujo primeiro fator foi constituído por sete extratos aquosos das espécies canola, crotalária, braquiária, girassol, trigo, tremoço e água, e o segundo fator diferentes partes botânicas das plantas. Os extratos na concentração de $5 \%$ foram aplicados na dose de $20 \mathrm{~mL}$ por planta. As variáveis agronômicas analisadas foram: altura de planta (AP), diâmetro de caule (DC), índice de área foliar (IAF), matéria seca foliar (MSF), matéria seca radicular (MSR) e comprimento radicular (CR). Houve diferença estatística para a variável AP dentro do fator Extrato, para a variável AP e MSF no fator Parte botânica e para a variável DC na interação entre os fatores. O extrato de braquiária para AP obteve o melhor resultado independente da parte botânica que o constituía, proporcionando um incremento de $3,77 \mathrm{~cm}$ em relação ao extrato de canola. $\mathrm{O}$ caráter agronômico mais sensível à aplicação de extratos aquosos foi a altura da planta, na qual o extrato de braquiária se destacou com maior crescimento, enquanto o extrato de canola dificultou o desenvolvimento inicial de mudas de café arábica.

Palavras-chave: alelopatia, Coffea arabica L., consórcio de plantas. 


\section{Introduction}

Coffee is a perennial plant with slow initial growth, and hence it has low competitiveness with weeds, which are aggressive and have faster vegetative development, and can be more efficient compared to coffee in the competition for production factors. In the quest to reduce the effects of weed competition, physical, cultural, and chemical controls are carried out (Costa et al., 2018).

Chemical control is the commonly used method, which increases weed selection pressure. However, the aspects that should be favored in this system would be the acceleration of the initial development of the coffee tree through genetic improvement, reduction in spacing between plants (Nunes et al., 2010), or the addition of some exogenous product.

To improve sustainability in agricultural production systems, there is a tendency to reduce synthetic chemical inputs to agroecosystems by using allelopathic natural products such as aqueous plant extracts (Tur et al., 2010). According to Silva et al. (2011), the term allelopathy is used to define the chemical interaction that occurs between organisms from the release of substances from the secondary metabolism of plants, the so-called allelochemicals. The International Allelopathy Society adds that secondary metabolites are also produced by algae, bacteria, or fungi, which can influence the growth and development of plants and biological systems in general (Scognamiglio et al., 2015).

The release of these secondary compounds occurs through processes such as root exudation, volatilization of compounds and decomposition of residues, and allelochemicals are commonly used as an alternative to herbicides, insecticides, and pesticides (Borella and Pastorini, 2009). These substances alter the biochemical and physiological conditions of the recipient species (Reigosa et al., 1999), interfere with seed conservation, dormancy and germination, seedling growth, and vegetative vigor of adult plants. According to Oliveira et al. (2002), varying levels of vegetative vigor have different degrees of effect on the competition between species and interfere in the natural regeneration or growth of species introduced in a given area, influencing the constitution of natural or artificial ecosystems.

The effects of allelochemicals are studied with emphasis on the initial development of plants in the seedling phase. Kalburtji (1999) found that leaf extracts from the crop itself inhibited germination of wheat caryopsis (Triticum aestivum L.), also affecting seedling development. Bortolini and Fortes (2005) found that root exudates from wheat (Triticum aestivum L.), triticale (Triticum sp.), corn (Zea mays L.), vetch (Vicia sativa L.), and black oats (Avena strigosa Schreb) impact the germination percentage of soybean seeds (Glycine max (L.) Merr.). However, regarding coffee cultivation, there is little research aimed at observing the effects of allelochemicals on the development of plants in stages later than seedlings. This study aimed to evaluate the initial development of coffee seedlings with the application of plant extracts from various botanical families.

\section{Material and Methods}

The experiment was conducted at the Horticulture and Biological Control Experimental Station Professor Mário César Lopes (latitude $24^{\circ} 46^{\prime} \mathrm{S}$, longitude $54^{\circ} 22^{\prime}$ $\mathrm{W}$ and altitude of $420 \mathrm{~m}$ ), belonging to the State University of Western Paraná, Campus Marechal Cândido Rondon - PR, in a greenhouse, during the period from October 2, 2017, to January 29, 2018, totaling 120 days after application of treatments. The temperature data for the experimental period were obtained using data logger equipment (Figure 1).

The soil used as substrate in the experiments is classified as dystrophic Red Latosol of very clayey texture $\left(615 \mathrm{~g} \mathrm{~kg}^{-1}\right.$ of clay, $258 \mathrm{~g} \mathrm{~kg}^{-1}$ of silt and $127 \mathrm{~g} \mathrm{~kg}^{-}$ ${ }^{1}$ of sand). The portion of soil collected for the installation of the experiments was sieved ( $2 \mathrm{~mm}$ mesh). Then, samples were collected at random and sent for analysis, to characterize the chemical and physical attributes of the soil. The results of the chemical analysis of the soil before the experiments commenced was: $\mathrm{pH}$ in $\mathrm{CaCl}_{2}=4.55$; Organic matter $=1.37 \mathrm{~g} \mathrm{dm}^{-3} ; \mathrm{P}=0.06 \mathrm{mg} \mathrm{dm}^{-3} ; \mathrm{Ca}^{+2}=$ $0.67 \mathrm{cmol}_{\mathrm{c}} \mathrm{dm}^{-3} ; \mathrm{Mg}^{+2}=0.08 \mathrm{cmol}_{\mathrm{c}} \mathrm{dm}^{-3} ; \mathrm{K}^{+}=0.08 \mathrm{cmol}_{\mathrm{c}}$ $\mathrm{dm}^{-3} ; \mathrm{Al}^{+3}=0.40 \mathrm{cmol}_{\mathrm{c}} \mathrm{dm}^{-3} ; \mathrm{H}+\mathrm{Al}=2.67 \mathrm{cmol}_{\mathrm{c}} \mathrm{dm}^{-3}$, $\mathrm{SB}=0.83 \mathrm{cmol}_{\mathrm{c}} \mathrm{dm}^{-3} ; \mathrm{CTC}=3.50 \mathrm{cmol}_{\mathrm{c}} \mathrm{dm}^{-3} ; \mathrm{V}=$ $23.77 \%$; and $\mathrm{m}=32.45 \%$.

A randomized block design with four replications was used in a $7 \times 2$ factorial scheme, with a total of 14 treatments and 48 plots. The first factor consisted of aqueous extracts from six plant species: canola (Brassica napus L.), crotalaria (Crotalaria juncea L.), brachiaria (Brachiaria decumbens L.), sunflower (Helianthus annus L.), wheat (Triticum aestivum L.), and lupine (Lupinus albus L.), and water was used as the control. The second factor was composed of different botanical parts of the plants (aerial and root systems). It consisted of three seedlings of the cultivar IPR 107, contained in $5 \mathrm{~L}$ pots.

The cultivar IPR 107 was used in the experiment as it combined the characteristics of the rusticity of the Mundo Novo cultivar and the characteristics of the cultivar IPR 59 (small and compact size, and resistant to rust) (Sera and Sera, 2013). The seedlings used were obtained from an accredited nursery, with five pairs of permanent leaves and a pair of jaguar-type leaves (first pair of leaves after germination), which remained in a semi-protected area for 15 days for acclimatization. Irrigation was performed by spraying, with a $10 \mathrm{~mm}$ water depth. Seven days before the transplant, protective fungicide was applied (2 $\mathrm{kg} \mathrm{ha}^{-1}$ of copper chloride oxide). 


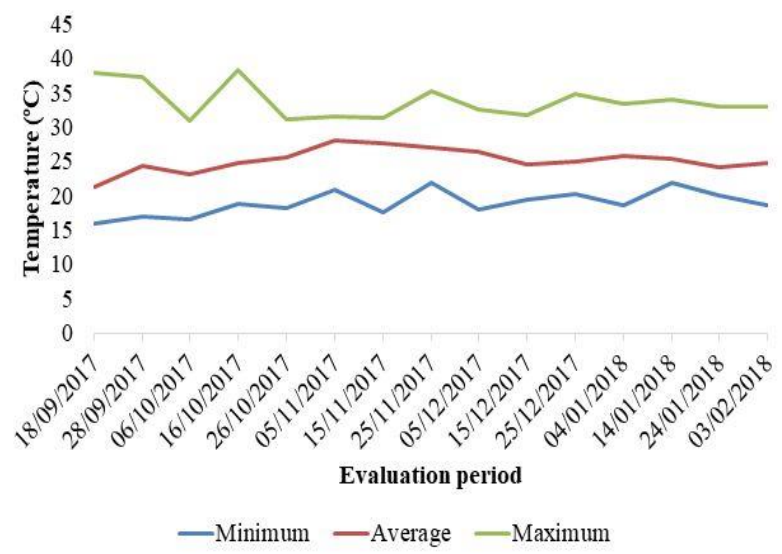

Figure 1. Air temperature throughout the experiment, which was carried out in a greenhouse.

To obtain the aqueous extracts for the first experimental factor, five pots of each of the six different plant species were sown. After 30 days, when the plants were in the vegetative phase, the removal of plant material was performed, with the aerial parts and roots collected separately. These were washed, weighed and crushed in a blender in the proportion of $20 \mathrm{~g}$ of vegetable material to $80 \mathrm{~mL}$ of water, to obtain the crude extract. This was diluted to $5 \%$ concentration, and then filtered through a vacuum filter and used immediately after preparation.

The experiment was carried out in polyethylene pots with a capacity of $5 \mathrm{dm}^{3}$, containing previously autoclaved soil $\left(120{ }^{\circ} \mathrm{C}\right.$ at $1 \mathrm{~atm}$, for $\left.1 \mathrm{~h}\right)$. Liming was then carried out, adding the equivalent of $2 \mathrm{t} \mathrm{ha}^{-1}$ of dolomitic limestone, and implantation fertilization with the equivalent of $116 \mathrm{~kg} \mathrm{ha}^{-1}$ of the commercial formulation 20-5-10 (N- $\left.\mathrm{P}_{2} \mathrm{O}_{5}-\mathrm{K}_{2} \mathrm{O}\right)$, following the procedures outlines in the fertilization and liming manual for the state of Paraná (SBCS, 2017) and the need for culturing for chemical analysis.

Seedlings of the Arabica coffee cultivar IPR 107 were transplanted to the afore-mentioned pots shortly after the substrate was prepared. Fifteen days after transplanting, the treatments were applied, and $20 \mathrm{~mL}$ of plant extracts (obtained as described above) were sprayed onto each coffee plant. After 120 days of application of extracts, the following agronomic traits were evaluated: plant height $(\mathrm{PH})$, stem diameter (SD), leaf area index (LAI), leaf dry matter (LDM), root dry matter (RDM), and root length (RL).

Values of plant height (PH), width, and length of leaves, measured with a millimeter ruler, were used to determine the LAI (Barros and Maestri, 1974). Stem diameter (SD) was measured in the lower third of the plant, using a digital caliper. The aerial parts were then abscised near the ground using pruning shears, labeled, and stored in a paper bag for later determination of LDM.

With care taken not to damage the root system, it was carefully separated from the soil in the pots, washed to remove any remaining soil particles, then dried with paper towels. Measurement of the root lengths (RL) were taken with a tape measure, and RDM was determined later.

For the determination of LDM and RDM, the samples were dried in an oven with forced air circulation, at a temperature of approximately $65{ }^{\circ} \mathrm{C}$, for 48 hours. After that, they were weighed on an analytical balance with a precision of $0.0001 \mathrm{~g}$.

The data obtained were submitted to normality and homogeneity tests, followed by an analysis of variance (ANOVA). As the ANOVA indicated significant differences in the sample means, they were compared using the Tukey test ( $\mathrm{p} \leq 0.05$ ), using the statistical program R (R Core Team, 2016).

\section{Results and Discussion}

The ANOVA showed statistically significant differences for PH within the extract factor, $\mathrm{PH}$ and LDM in the botanical part factor (BotP), the interaction between factors, and the SD (Table 1). The other variables did not show significantly different values (Table 1).

The PH may have been influenced by the environmental conditions which the seedlings were exposed to, as increases in the average air temperature and the number of light-hours are known to physiologically stimulate vegetative growth in young coffee plants (Silva et al., 2004). In addition to the genetic factors influencing the coffee plant, the increase in plant height may have been stimulated by the secondary metabolites of the plant extracts applied, as well as effects from the different BotP, and the combination of these two factors. The SD results may indicate that coffee plants have greater storage capacity for photoassimilates than other species; and that this variable was more sensitive to the different extracts and their interaction with the different botanical parts of the applied plant extracts.

Even though the LAI values were not significant, probably caused by the accelerated pace of leaf production and development, LDM exhibited differing sensitivity to plant extracts from the various BotP that constituted them. The different amounts of allelochemicals in BotP possibly influenced this variable (LDM).

The PH was influenced by the plant extracts and the BotP that constituted them. The extracts produced from the root systems obtained higher averages than those of the aerial parts with an increase of $3.07 \%$ (Table 2).

The vegetable extract that obtained the best result was prepared with brachiaria, regardless of the BotP that constituted it. Regarding the difference between the highest and lowest average treatments, the brachiaria 
extract provided an increase of $3.77 \mathrm{~cm}$ compared to the canola extract, representing a 15\% gain in IPR 107 plant height (Table 2).

Freitas and Viecelli (2011) evaluated the effects of ryegrass allelopathy on the germination and early growth of wheat, observing that at a concentration of $10 \%$, extracts produced from the aerial parts of ryegrass were beneficial to the variables of growth and accumulation of dry matter. In the present experiment, the same behavior was observed for brachiaria (the same botanical family of ryegrass), which provided the best results both for the plant height variable (regardless of the BotP used to produce the extract). The canola extract showed lower averages than the control and it can be inferred that it had negative effects on $\mathrm{PH}$.

Canola belongs to the Brassicaceae botanical family, which has recognized allelopathic activity and from which glucosinolates, chemical compounds with high herbicidal power, are synthesized (Oerlemans et al., 2006). It is presumed that even in small concentrations $(5 \%)$ similar to that used in the present study, the action of glucosinolates and other allelochemical compounds influence the development of the coffee plant (both in height and in diameter), which was therefore sensitive to the aqueous extract produced mainly from the canola root system.

Table 1. Summary of analysis of variance with the mean square of plant height (PH), stem diameter (SD), leaf area index (LAI), leaf dry matter (LDM), root dry matter (RDM), and root length (RL) depending on the application of botanical part factor (BotP).

\begin{tabular}{|c|c|c|c|c|c|c|c|}
\hline SV & DF & $\mathrm{PH}(\mathrm{cm})$ & $\mathrm{SD}(\mathrm{mm})$ & $\operatorname{LAI}\left(\mathrm{cm}^{2}\right)$ & $\operatorname{LDM}(\mathrm{g})$ & RDM (g) & $\mathrm{RL}(\mathrm{cm})$ \\
\hline Block & 3 & $11.1778 *$ & $0.36525^{\mathrm{ns}}$ & 42.994 ns & $3.2781^{\mathrm{ns}}$ & $0.03421^{\mathrm{ns}}$ & $0.1862^{\mathrm{ns}}$ \\
\hline Extract & 6 & $10.5537 *$ & $0.39492 \mathrm{~ns}$ & $25.837 \mathrm{~ns}$ & $1.8945^{\mathrm{ns}}$ & $0.26278^{\mathrm{ns}}$ & $6.4152 \mathrm{~ns}$ \\
\hline BotP & 1 & $13.3087 *$ & $0.34414^{\mathrm{ns}}$ & 44.893 ns & $6.3316^{*}$ & $0.01059^{\mathrm{ns}}$ & $7.1429^{\mathrm{ns}}$ \\
\hline Extract* PBot & 6 & $3.5400^{\mathrm{ns}}$ & $1.05142 *$ & $81.233^{\mathrm{ns}}$ & $2.0877^{\mathrm{ns}}$ & $0.44304^{\mathrm{ns}}$ & $13.0999 \mathrm{~ns}$ \\
\hline Error & 39 & 2.7411 & 0.39337 & 64.307 & 1.4104 & 0.34554 & 17.1409 \\
\hline CV (\%) & & 6.15 & 11.51 & 34.33 & 18.28 & 26.73 & 23.37 \\
\hline
\end{tabular}

Note. $\mathrm{SV}=$ Source of variation, $\mathrm{DF}=$ degrees of freedom, $\mathrm{BotP}=$ botanical part, $\mathrm{CV}=$ coefficient of variation $*=$ significant at $5 \%$, ns $=$ not significant.

Table 2. Average plant height (PH), stem diameter (SD), leaf area index (LAI), leaf dry matter (LDM), root dry matter (RDM), and root length (RL); depending on the application of aqueous extracts obtained from the aerial part (AP) and the root system (RP) of plant species (BotP).

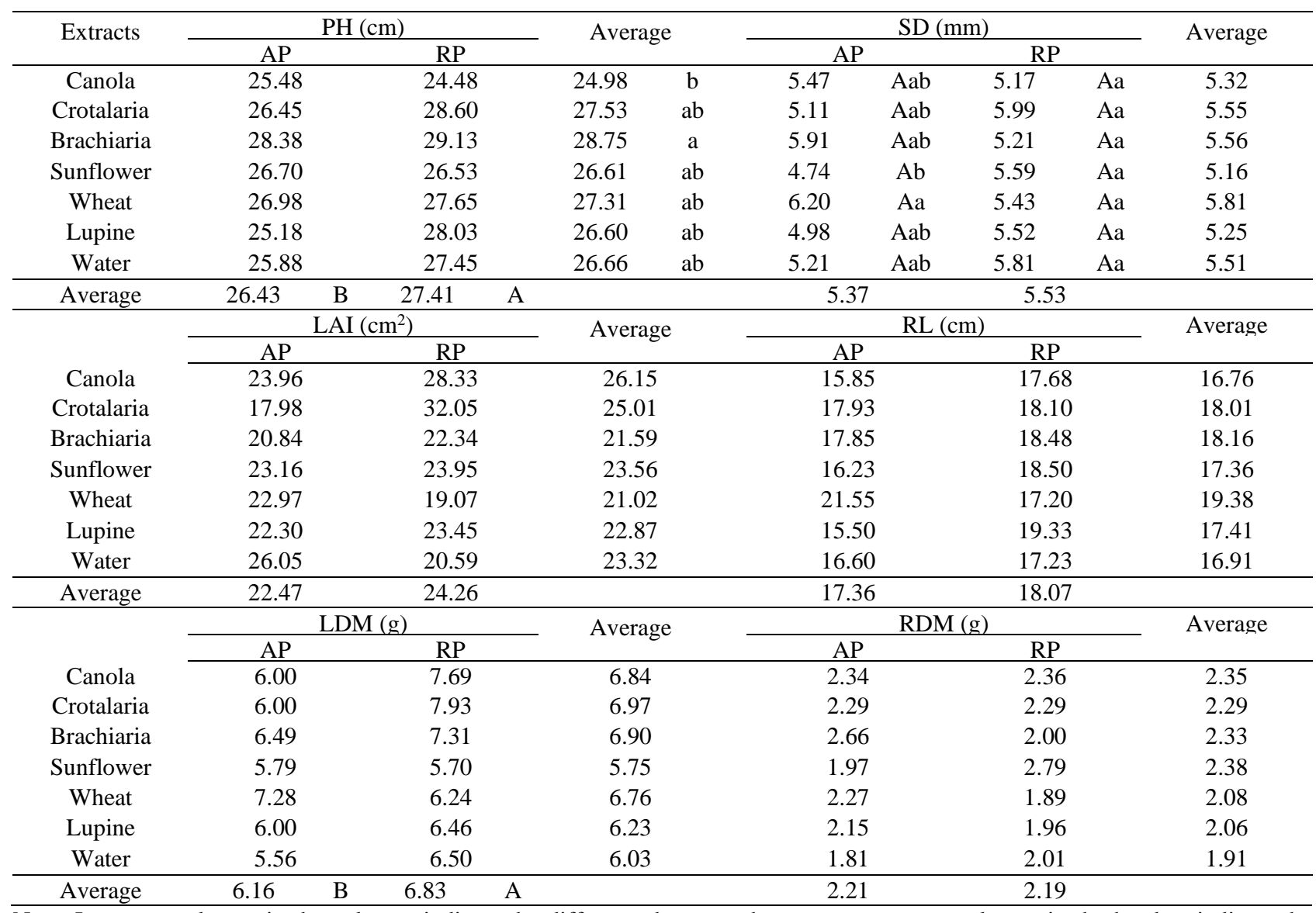

Note. Lower case letters in the columns indicate the difference between the extracts, uppercase letters in the headers indicate the botanical parts: aerial parts (AP) and root parts (RP), according to Tukey's test at a 5\% probability of error. 
Rizzardi et al. (2008a) in a study evaluating the allelopathic potential of aqueous extracts of canola genotypes on Bidens pilosa, observed that low concentrations $(25 \%)$ of extracts from different genotypes exerted inhibitory effects on the target species. These authors indicated that the production of glucosinolate allelochemicals gives rise to isothiocyanates during hydrolysis, which have an evident allelopathic herbicidal effect on a number of plant species.

Notably, not all species are negatively influenced by the allelochemicals produced by canola, and some may even benefit from the addition of this species to the production system. Similarly, studying the allelopathic potential of canola (Brassica napus L. var. Oleifera) on the suppression of black pepper (Bidens sp.) and soy, Rizzardi et al. (2008b) clarified the inhibitory effects of canola on weeds; and that it improves soybean culture when deposited in the soil in straw form, by reducing the germination of weeds through the sum of physical and phytotoxic factors.

For SD, an interaction was observed between the extract factors and the BotP. There was no significant difference from using extracts obtained from the root system, but the results were significantly different from use of the extracts produced by the aerial systems, and especially prominent in the use of wheat-based extract. The sunflower extracts provided a reduction of $1.46 \mathrm{~mm}$ in the SD in relation to the wheat extract.

The sunflower has several products originating from secondary metabolism, such as phenols and terpenes; substances that act in defense against attacks from herbivores, insects, and fungi, in addition to limiting the growth of other plants (Taiz et al., 2017). The SD results were possibly sensitive to the inhibitory effects of these compounds. In studies by Bernat et al. (2004), using aqueous extracts from the aerial parts of sunflower plants on mustard and wheat, they observed a reduction in both germination and aerial development of the evaluated species. The same behavior was observed in this experiment. In a study on the allelopathic effect of green manure formed by different botanical parts of sunflower plants on the development of two corn hybrids (Zea mays L.), a transgenic and a conventional one, Roncatto and Viecelli (2009) found that lower concentrations of sunflower extracts positively influenced corn growth, a behavior similar to that observed in this experiment.

The LAI, RDM and RL were not influenced by aqueous extracts. The allelopathic potential of the aqueous extract of wheat was evaluated by Tokura and Nóbrega (2005), who observed an increase in LDM and RL. Corsato et al. (2010), when using aqueous extract of sunflower leaves in the initial stage of soybean culture and Bidens pilosa L., reported that root growth was inhibited by different doses of extract. This was not the same behavior observed in the present study, and may be due to the fact that both the aforementioned studies were performed on temperate crops, which have different growth rates to perennial crops.

For LDM, the BotP was significantly different. The results from using extracts from root parts were $10.9 \%$ higher than those using extracts from the aerial parts, with an increase of $0.67 \mathrm{~g}$. Among the extracts from the root system, mean LDM was $5.70 \mathrm{~g}$ and $7.63 \mathrm{~g}$, from plants sprayed with sunflower extracts and crotalaria respectively, representing a difference of $33.85 \%$.

The use of plant extracts can stimulate the synthesis of secondary metabolites as well as stress, caused by the action of different biotic and abiotic agents (Taiz et al., 2017). These metabolites can act at the cellular level and impair the selective transport of cell membranes. An action that may have influenced the effect observed on $\mathrm{PH}$, and consequently, on LDM and RL, as shown in this experiment.

\section{Conclusions}

The agronomic character of Arabica coffee seedlings most sensitive to the application of aqueous extracts during their initial development was $\mathrm{PH}$, with brachiaria extract leading to greatest growth and canola extract hindering initial development of Arabica coffee seedlings.

\section{Acknowledgements}

This work was carried out with the support of the Coordination for the Improvement of Higher Education Personnel - Brazil (CAPES) - Financing Code 001.

\section{Bibliographic References}

Barros, R.S., Maestri, M., 1974. Influence of climatic factors on growth periodicity of coffee (Coffea arabica L.). Revista Ceres, 21(1), 268-279.

Bernat, W., Gawronska, H., Janowiak, F., Gawronski, S.W., 2004. The effect of sunflower allelopathycs on germination and seedling vigour of winter wheat and mustard. Zeszyty Problemowe Postepow Nauk Rolniczych, 496(1), 289-300.

Borella, J., Pastorini, L.H., 2009. Allelopathic influence of Phytolacca dioica L. germination and early growth of Lycopersicum esculentum and Bidens pilosa. Biotemas, 22(3), 67-75.

Bortolini, M.F., Fortes, A.M.T., 2005. Efeitos alelopáticos sobre a germinação de sementes de soja (Glycine max L. Merrill). Semina: Ciências Agrárias, 26(1), 5-10.

Corsato, J.M., Fortes, A.M.T., Santorum, M., Raquel Leszczynski, R., 2010. Allelopathic effect of sunflower water extract on the germination of soybean and hairy beggartick. Semina: Ciências Agrárias, 31(2), 353-360. 
Costa, N.V., Rodrigues-Costa, A.C.P., Coelho, E.M.P., Ferreira, S.D., Barbosa, J.A., 2018. Methods of weed control in organic systems: a short review. Revista Brasileira de Herbicidas, 17(1), 25-44.

Freitas, C.D., Viecelli, C., 2011. Interference azevém alelopática in the germination and initial development of wheat plants. Cultivando o Saber, 4(3), 37-46.

Kalburtji, K.L., 1999. Research on allelopathy in Greece, in: Narwal, S.S. (Eds.). Allelopathy Update. Enfield, Science Pub., p. 37-47.

Nunes, A.L., Trezzi, M.M., Debastiani, C., 2010. Integrated weed management in maize cultivation. Bragantia, 69(2), 299304.

Oerlemans, K., Barrett, D.M., Suades, C.B., Verkerk, R., Dekker, M., 2006. Thermal degradation of glucosinolates in red cabbage. Food Chemistry, 95(1), 19-29.

Oliveira, N.S., Mercadante, M.O., Lopes, P.S.N., Gomes, I.A.C., Pereira, E.G., Ribeiro, L.M., 2002. Efects of aqueous and ethanolic extracts. Unimontes Científica, 4(2), 1-12.

R Core Team, 2016. R: A Language and Environment for Statistical Computing. R Foundation for Statistical Computing, Vienna, Austria.

Reigosa, M.J., Sánchez-Moreiras, A., Gonzáles, L., 1999. Ecophysiological approach in allelopathy. Critical Reviews in Plant Sciences, 18(5), 577-608.

Rizzardi, A., Rizzardi, M.A., Lamb, T.D., Johann, L.B., 2008a. Allelopathic potential of aqueous extracts of canola genotypes on Bidens Pilosa. Planta Daninha, 26(4), 717-724.

Rizzardi, M.A., Neves, R., Lamb, T.D., Johann, L.B., $2008 b$. Allelopathic potential of canola crop (Brassica napus L. var. oleifera) on suppression of hairy beggar ticks (Bidens sp.) and soybean. Revista Brasileira de Agrociência, 14(2), 239-248.
Roncatto, F., Viecelli, C.A., 2009. Green manure for sunflower on the development of maize. Cultivando o Saber, 2(3), 1-6.

SBCS. Sociedade Brasileira de Ciência do Solo, 2017. Manual de Adubação e Calagem para o Estado do Paraná. Curitiba, SBCS/NEPAR.

Scognamiglio, M., Abrosca, B.D., Esposito, A., Fiorentino, A., 2015. Metabolomics: an unexplored tool for allelopathy studies. Journal of Allelochemical Interactions, 1(1), 9-23.

Sera, T., Sera, G.H., 2013. IPR 107 - cultivar de café árabe anão com resistência à ferrugem do café. Crop Breeding and Applied Biotechnology, 13(3), 215-217.

Silva, E.A., Mata, F.M., Ducatti, C., Regazzi, O., Barros, R.S., 2004. Seasonal changes in vegetative growth and photosynthesis of Arabica coffee trees. Field Crops Research, 89(2-3), 349-357.

Silva, J., Fortes, A.M.T., Gomes, F.M., Pinto, T.T., Bonamigo, T., Boiago, N.P., 2011. Allelopathy of Camelina sativa Boiss. (Brassicaceae) on germination and early development of Bidens pilosa (L.) and Glycine max (L.) Merr. Biotemas, 24(4), 14-24.

Taiz, L., Zeiger, E., Moller, I.M., Murphy, A., 2017. Plant Physiology and Development, sixth ed. Sinauer Associates, Sunderland.

Tokura, L.K., Nóbrega, L.H.P., 2005. Cover crop allelopathic potential in the development of corn seedlings. Acta Scientiarum. Agronomy, 27(3), 287-292.

Tur, C.M., Borella, J., Pastorini, L.H., 2010. Allelopathic effects of aqueous extracts of Duranta repens on the germination and early growth of Lactuca sativa and Lycopersicum esculentum. Biotemas, 23(2), 13-22. 